\title{
Histopathological findings in 29 lymph node biopsies with increased IgG4 plasma cells
}

\author{
Kate E Grimm ${ }^{1}$, Todd S Barry ${ }^{1}$, Vladislav Chizhevsky ${ }^{1}$, Anselm Hii ${ }^{1}$, Lawrence M Weiss ${ }^{1}$, \\ Imran N Siddiqi ${ }^{2}$, Russell K Brynes ${ }^{2}$ and Dennis P O’Malley ${ }^{1,3}$ \\ ${ }^{1}$ Clarient /GE Healthcare, Department of Pathology, Aliso Viejo, CA, USA; ${ }^{2}$ University of Southern California, \\ Los Angeles County Hospital, Los Angeles, CA, USA and ${ }^{3} M D$ Anderson Cancer Center, University of Texas, \\ Department of Hematopathology, Houston, TX, USA
}

\begin{abstract}
IgG4-related sclerosing disease encompasses a family of disorders associated with increased numbers of IgG4 plasma cells and mass forming lesions in various tissues. Lymphadenopathy is a common finding, seen in up to $80 \%$ of cases. In the largest series of cases to date, we describe histologic, immunohistochemical, special stain and flow cytometric findings in 29 cases of enlarged lymph nodes with increased IgG4 plasma cells. Lymph node biopsies showed all resection specimens; no needle core biopsies of tissue were evaluated. Cases were considered to have increased numbers of IgG4 plasma cells using the histological criteria outlined by Cheuk and Chan (2010): IgG4 plasma cells $>\mathbf{5 0}$ cells in a high-power field and $>\mathbf{4 0} \%$ of IgG-positive plasma cells positive for IgG4. Additionally, increased intrafollicular plasma cells were a common finding. The lymph nodes showed a variety of reactive histological features including follicular hyperplasia, progressive transformation of germinal centers, interfollicular expansions, variable degrees of fibrosis, increased histiocytes and occasionally an appearance similar to that of plasma cell Castleman disease.

Modern Pathology (2012) 25, 480-491; doi:10.1038/modpathol.2011.177; published online 11 November 2011
\end{abstract}

Keywords: IgG4; IgG4-related sclerosing disease; lymph node; reactive lymphadenopathy

IgG4-related sclerosing disease is a relatively recently described systemic clinicopathological entity that unifies a number of previously described diseases under one heading. The unifying histological features are fibrosis and an increased number of IgG4 plasma cells. Originally described as a unique form of autoimmune pancreatitis, ${ }^{1}$ IgG4-related sclerosing pancreatitis was typically encountered in older males with a striking clinical mimicry of pancreatic carcinoma, frequent relapse, elevated serum IgG4 levels and a marked response to steroid therapy. ${ }^{1-3}$ Histological findings demonstrated a combination of fibrosis and lymphoplasmacytic infiltrate with increased numbers of IgG4 plasma cells. ${ }^{4}$ More recently, we have come to understand that the pancreatic disease was only one of the many manifestations of this disease. Mass-forming lesions with increased IgG4 plasma

Correspondence: Dr DP O’Malley, MD, Department of Pathology, Clarient /GE Healthcare, 31 Columbia, Aliso Viejo, CA 92656, USA.

E-mail: domalley@clarientinc.com

Received 19 July 2011; revised 7 September 2011; accepted 7 September 2011; published online 11 November 2011 cells have been reported in numerous sites and disorders: central nervous system, lacrimal gland (Mikulicz's disease), sclerosing sialadenitis (Kuttner tumor), thyroid gland, pulmonary lesions, breast tissue, liver, retroperitoneal fibrosis, inflammatory aortic aneurysm, kidney, skin and lymph node. ${ }^{4}$ Increased IgG4 cells in lymph nodes or IgG4-related lymphadenopathy, may precede, coexist with, or follow extranodal manifestations of the disease. Laboratory findings seen in a subset of these patients include increased serum levels of IgG, IgG4 or IgE. Additionally, an elevated sedimentation rate and autoantibodies have also been reported. ${ }^{5}$

The IgG4 antibody is the rarest subset of all $\operatorname{IgG}$ antibodies. Normally, IgG4 plasma cells represent $3-6 \%$ of IgG plasma cells in tissues. ${ }^{5}$ The different subclasses of IgG vary in their amino-acid composition in their hinge region, which results in different antigen binding and effector capabilities. Some features of IgG4 plasma cells, in contrast to other IgG types, are that they lack the ability to fix complement, and their proliferation is driven by Th2 cytokines. ${ }^{4}$ IgG4-positive plasma cells may cause a reduction in inflammatory responses after chronic exposure to antigen. IgG4 antibodies show a 
unique feature of Fab-arm exchange in which they swap one of their heavy and light chain halves with another molecule, resulting in a bi-specific antibody. ${ }^{6} \mathrm{~A}$ mechanism to explain the role of increased numbers of IgG4 plasma cells in the systemic disease has not been clearly delineated yet.

Patients who have been diagnosed with IgG4related sclerosing pancreatitis, frequently have enlarged lymph nodes $(80 \%){ }^{5}$ The histological findings observed in these patients' lymph nodes have been used to define a set of diagnostic criteria for recognizing IgG4-related lymphadenopathy. Five histological patterns have been reported in the literature associated with IgG4-related lymphadenopathy, which have previously been described in predominantly Asian populations. These patterns are: multicentric Castleman disease-like, follicular hyperplasia, interfollicular expansion, progressive transformation of germinal centers and nodal inflammatory pseudotumor-like. ${ }^{5,7-9}$ We selected cases with these histological findings and other features of benign adenopathy in adult patients, and evaluated for IgG and IgG4 by immunostaining.

In an effort to increase recognition and diagnosis of IgG4-related lymphadenopathy, we present the largest series to date of lymph nodes with increased IgG4 plasma cells. We describe the histological, cytochemical, immunohistochemical and flow cytometrical findings of these cases in our ethnically diverse patient population.

\section{Materials and methods}

Cases for review were selected from consultation cases received at Clarient /GE Healthcare (Aliso Viejo, CA, USA) and from Los Angeles Country/ University of Southern California Hospital (Los Angeles, CA, USA). These cases showed histological findings described in IgG4-related lymphadenopathy in adults with benign and reactive findings. The research was performed in accordance with institutional protocols for research.

Twenty-eight cases from Clarient and one case from USC were selected for further study. Attempts were made to obtain clinical follow-up, therapy and related manifestations of IgG4 and autoimmune disease. Unfortunately, because of the secondary referral nature of most of the materials, only very limited clinical findings and follow up were available.

In each of these cases, lymph nodes were evaluated using both standard hematoxylin and eosin (H\&E) staining and immunohistochemistry. In all cases, immunohistochemical stains were performed for CD3, CD20, CD138, IgG (Dako, Carpinteria CA, USA) and IgG4 (Maine Biotech Services, Portland, ME, USA) using standard methodologies. When appropriate for diagnostic evaluation, additional immunohistochemical stains, in situ stains or special histochemical stains for organisms were performed using standard methodologies. Histological and immunohistochemical evaluation was conducted for comparison and standardization of histological findings by two pathologists at a double-headed microscope (DPO, KEG). Results of IgG4 plasma cell staining were evaluated in the context of a concurrent IgG stain. Cases were considered to have increases in IgG4 plasma cells using the criteria outlined by Cheuk and Chan: ${ }^{5}$ an increased absolute number of IgG4 cells > 50/highpower field (HPF), and a percentage of IgG4positive/IgG-positive cells $>40 \%$. Quantitation of plasma cells was evaluated in areas of highest density of positive cells, and averaged over three high-power fields. Eosinophils were considered increased if five or more were seen per high-power field. The presence was then rated as rare $(1+)$, occasional $(2+)$ or frequent $(3+)$.

In ten cases, flow cytometry was also available for review. In these cases, tubes analyzed were as follows: tube 1: IgG1/IgG1/CD45/IgG1/IgG1; tube 2: surface $\kappa /$ surface $\lambda / C D 45 / C D 19 / C D 20$; tube 3: CD5/ CD23/CD45/CD19/CD10; tube 4: CD7/CD4/CD45/ CD8/CD2; tube 5: CD14/CD11c/CD45/CD22/CD38; tube 6: FMC7/CD3/CD45/CD16/CD56; viability tube: 7AAD. These cases were performed on BeckmanCoulter flow cytometry analyzers (Hialeah, Florida) and analyzed using FCS Express software (San Diego, California, USA).

An additional eighteen cases of benign and reactive conditions in lymph nodes were selected for comparison with the study cases. These cases were well-characterized as benign or reactive conditions using appropriate immunohistochemical, flow cytometric and molecular testing as appropriate in all cases. Many of these cases had some similar histological features to the study cases. In each of these cases, whereas IgG-positive plasma cells were present in varying degrees, rare or no IgG4-positive plasma cells were seen $(<1 / 10$ highpower fields).

\section{Results}

\section{Clinical}

Twenty-nine cases with increased numbers of IgG4 plasma cells were identified (Figures 1-6). The distribution of the IgG4-positive plasma cells was patchy and uneven within individual compartments of lymph nodes. The median age of patients was 57 years (19-83 years). Nineteen of the patients were female and ten were male. Ten cases were axillary lymph nodes, nine cervical, five inguinal, one mediastinal, one submental, one chest wall and two lymph node biopsies were from an unspecified site.

Because of the nature of our practice, clinical follow up was available on only a minimal number of cases. One patient had two separate lymph node biopsies at separate anatomic sites (case 5; cervical 


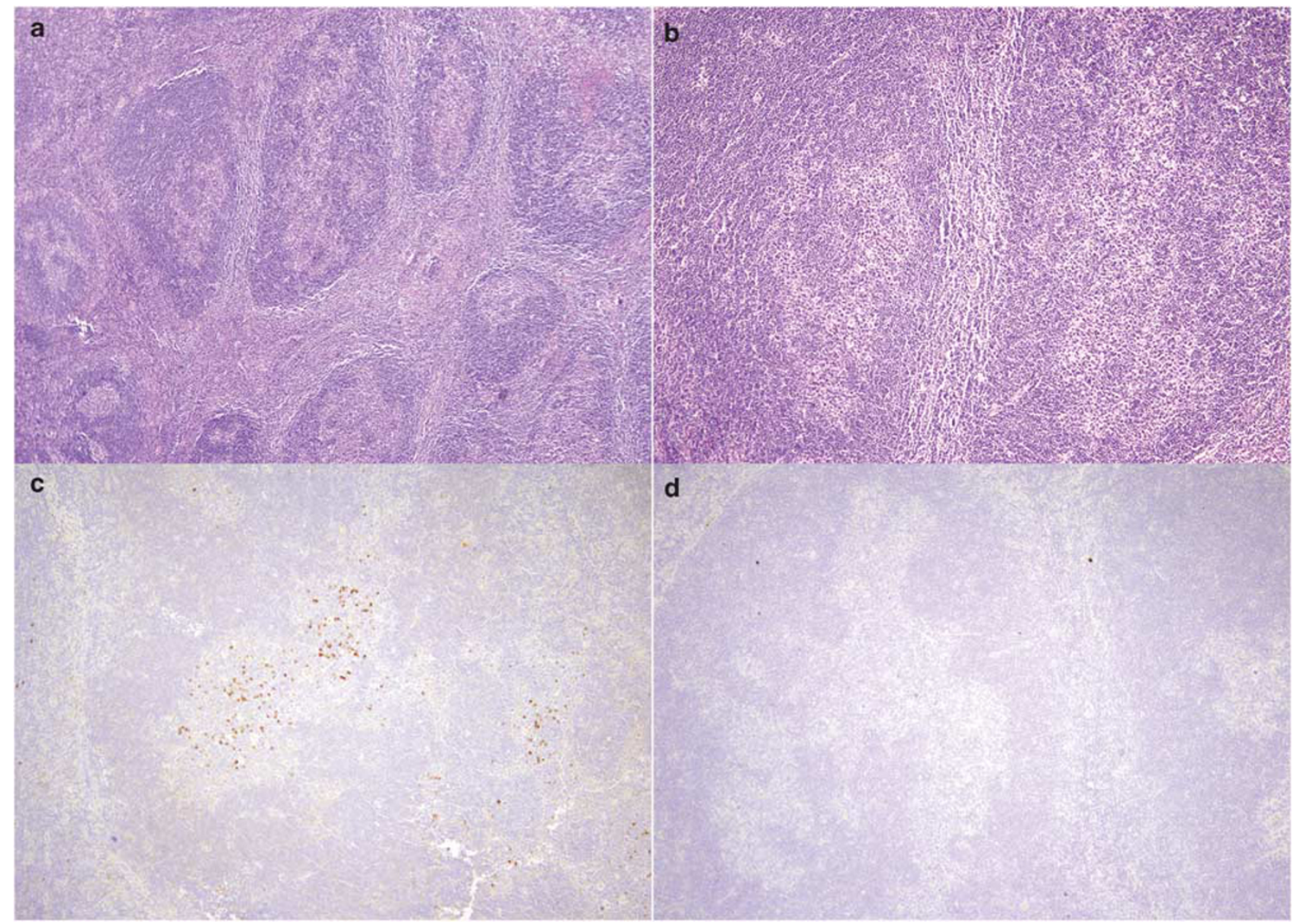

Figure 1 (a) low magnification, (b) intermediate magnification of reactive lymph node. Immunohistochemical staining for (c) IgG and (d) IgG4. Note that no IgG4-positive plasma cells are seen.

and mediastinal), showing similar histological and immunohistochemical findings. Only the cervical lymph node was used for further evaluation. Interestingly, in one case (Case 8) the patient was also noted to have pancreatitis and glucose intolerance with an elevated creatinine. Despite multiple attempts, additional follow-up information was not available. The findings of an elevated IgG4 serum level (serum IgG4 >135 mg/dl) was not supplied for these cases.

\section{Histology}

Histological findings are summarized in Table 1. All lymph nodes evaluated were enlarged in size. The capsules were intact; however, fibrotic thickening with plasmacytic infiltrate and minimal extracapsular lymphocytosis were observed in occasional cases. In all cases, lymphoid tissue showed benign hyperplasia of various lymph node compartments. Appropriate histological, immunohistochemical and special stains were performed to exclude more specific etiologies or abnormalities. No specific entities, infectious etiologies or lymphomas were supported by the histological or ancillary findings. These were compared with reactive lymph nodes with no increases in IgG4 plasma cells (Table 2).

Follicular hyperplasia was a common finding and was seen in $24 / 29$ ( $83 \%$ ) cases. The follicles showed germinal centers with typical benign features including polarization, tingible-body macrophages and well-formed mantle zones. Progressive transformation of germinal centers was seen in 14/29 cases (48\%). These cases showed typical features of progressively transformed germinal centers; large nodules, composed mostly of small dark blue, mantle-type lymphocytes. Admixed mostly in the central portion were more irregular germinal center-type lymphocytes including small irregular lymphocytes and occasional larger, transformed lymphocytes. In all cases, no Hodgkin's cells or LP cells were seen. The most common finding in the histological survey was an expanded interfollicular area, with prominent immunoblastic proliferation, a feature seen in 25/29 (86\%) cases. Although these cases demonstrated an increase in larger, transformed lymphocytes (eg immunoblasts) in the 


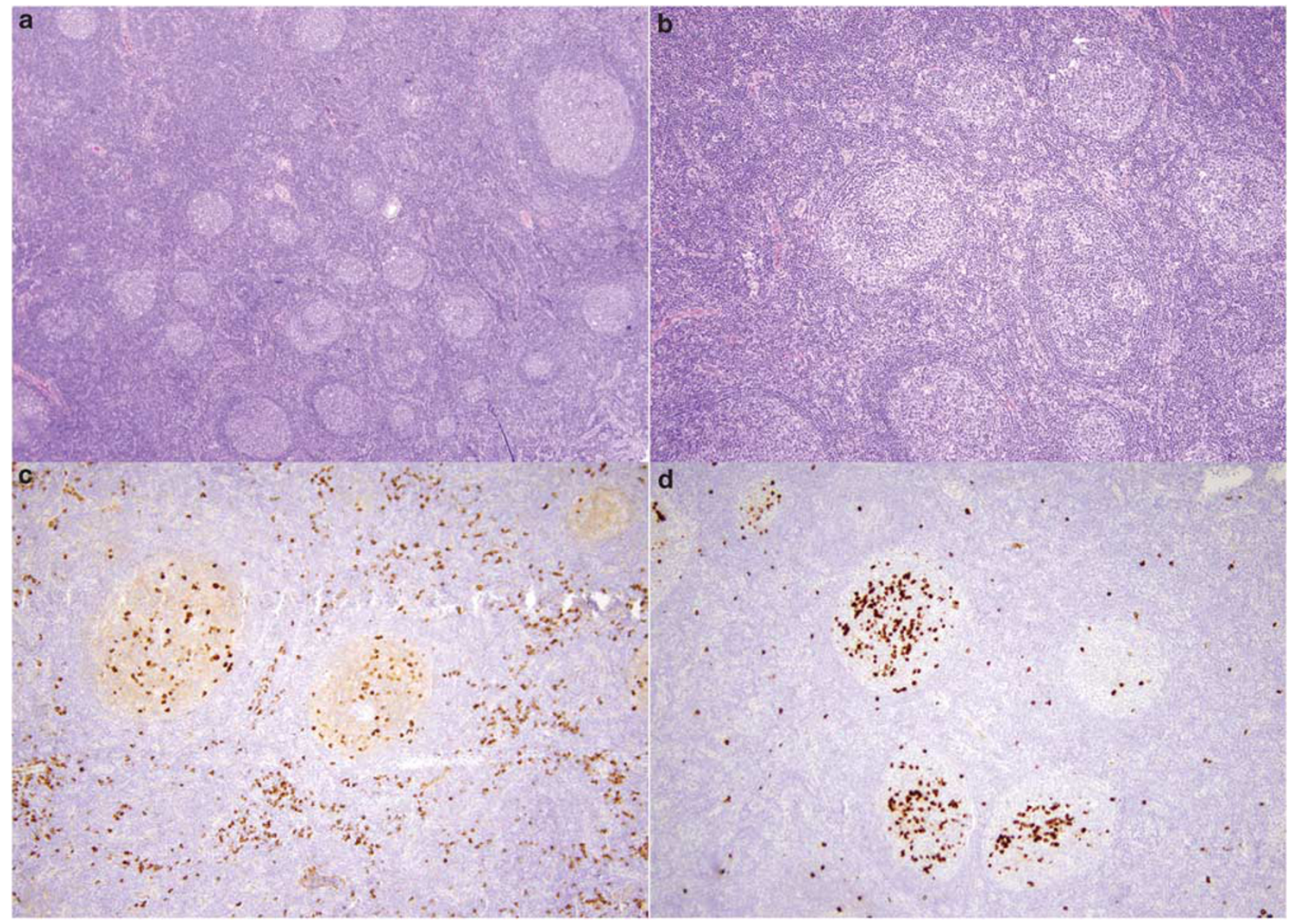

Figure 2 (a) low magnification, (b) intermediate magnification of follicular hyperplasia pattern of IgG4-related lymphadenopathy. Immunohistochemical staining for (c) $\operatorname{IgG}$ and (d) IgG4.

interfollicular areas, no diffuse sheets of large cells were seen.

In $20 / 29$ cases $(69 \%)$, there was an increase in interfollicular plasma cells. In some of these cases, the increase was of sufficient degree to suggest a diagnosis of plasma cell Castleman disease but lacked features of nodal plasmacytoma. These plasma cells were cytologically mature with no overtly atypical plasma cells or plasmablasts identified. In rare interfollicular plasma cells, Russell bodies (intracytoplasmic immunoglobulin deposits) and Mott cells (few or several clusters of immunoglobulin deposits) were identified. Rare, binucleated plasma cells were seen. Intrafollicular plasma cells were seen in 16/29 cases (55\%) (Figure 7). Some of these plasma cells showed prominent Russell bodies or a Mott-cell appearance.

Histiocytic proliferations were seen in 11/29 cases $(38 \%)$. Findings placed in this category were broad and included: (1) classic dermatopathic changes, (2) sinus histiocytosis, (3) rare giant cells, (4) epithelioid histiocytes in non-caseating granulomas and (5) in three cases (cases 19, 23, 28), a prominent ringing of follicles by epithelioid histiocytes.
Stromal/vascular proliferation was seen in 18/29 cases $(62 \%)$. These cases showed prominent high endothelial venules and increased stromal elements and bland, spindle cells. Significant fibrosis was seen in nine cases, 9/29 (31\%). It ranged from dense capsular fibrosis to small bands within the parenchyma of the lymph node, to near-total replacement of lymphoid tissue by fibroblasts (Cases 3, 9).

\section{Additional Histological and Immunohistochemical Findings}

No obliterative phlebitis was noted in any case. Increased eosinophils were seen in ten cases (cases 4, 9, 11, 14, 24; $1+$ eosinophils) (Cases 25, 27; $2+$ eosinophils) (Cases 18, 12, 28; $3+$ eosinophils). In all cases, increased eosinophils were present in interfollicular areas. In most cases, they were associated with areas of increased density of fibrous or stromal elements. Seventeen cases were tested for in situ expression of Epstein-Barr virus early RNA (EBER) (Cases 1, 2, 3, 4, 6, 9, 11, 12, 15, 16, 21, 23, 


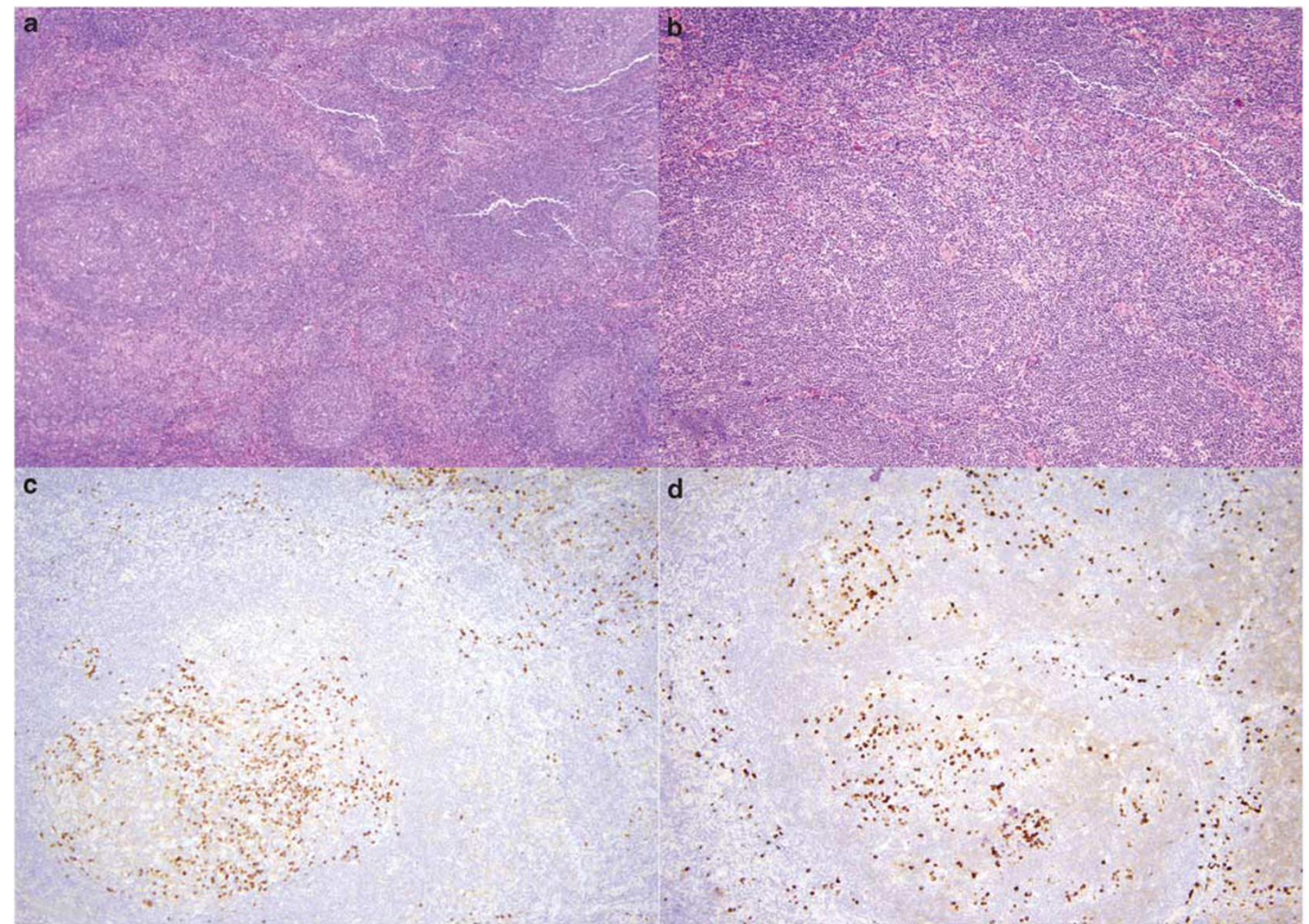

Figure 3 (a) low magnification, (b) intermediate magnification of progressive transformation of germinal centers. Immunohistochemical staining for (c) IgG and (d) IgG4 with a significant increase in IgG4-positive plasma cells.

24, 25, 26, 28, 29). Two cases (Cases 12, 28) showed rare individual germinal centers with focal EBER positivity, which was not specifically associated with areas of plasmacytosis; no other cases showed any staining for EBER. No organisms were identified by staining for Gomori methenamine silver or acid fast bacilli in six cases (Cases 3, 8, 18, 24, 25, 28; Table 2). No organisms were identified by WarthinStarry stains in three cases tested (Cases 3, 5, 8). Cases 8 and 24 were tested for Toxoplasma, and case 8 tested for tuberculosis using immunohistochemistry; no positive findings were identified. Six cases (Cases 1, 5, 13, 14, 18 , 27; Table 2) were tested for human herpes virus 8 (HHV8) by immunohistochemical staining and were negative.

S100 staining was done in four cases $(2,3,9,18)$; one case was also tested for CD1a (Case 2) showing co-expression of S-100 protein and CD1a staining on increased scattered Langerhans cells. Features of Rosai-Dorfman disease were not seen. Plasma cells were shown to be polyclonal in ten cases using in situ stains for kappa and lambda (Cases 1, 5, 8, 9, 11, 13, 14, 18, 25, 27). Polyclonal kappa and lambda staining was demonstrated by immunohistochemistry in three cases (Case 24, 25, 27).

\section{Flow Cytometry}

Ten cases had concurrent flow cytometry results on the lymph node specimens (Cases 2, 5, 6, 8, 11, 14, 15, 16, 23, 25). In all ten cases, CD4-positive T cells were increased compared with CD8 cells with CD4:CD8 ratios ranging from 3.36 to 11.24 . In four of these cases (Cases 2, 6, 8, 16), there was a small but discrete subset of T cells coexpressing CD4/CD8 accounting for 1-6\% of the lymphocytes analyzed. This finding was seen in four out of five (4/5) total cases with progressively transformed germinal centers seen histologically and concomitant flow cytometry.

\section{Discussion}

Our series addresses lymph nodes with a significant increase in IgG4 plasma cells, which by previously published criteria are diagnostic of IgG4-related lymphadenopathy. ${ }^{5}$ As stressed by Cheuk and Chan, ${ }^{5}$ an elevated serum IgG4 is 'helpful but not essential' for the diagnosis of IgG4-related sclerosing disease. Elevated numbers of IgG4 plasma cells in tissue is a more sensitive and specific finding than 


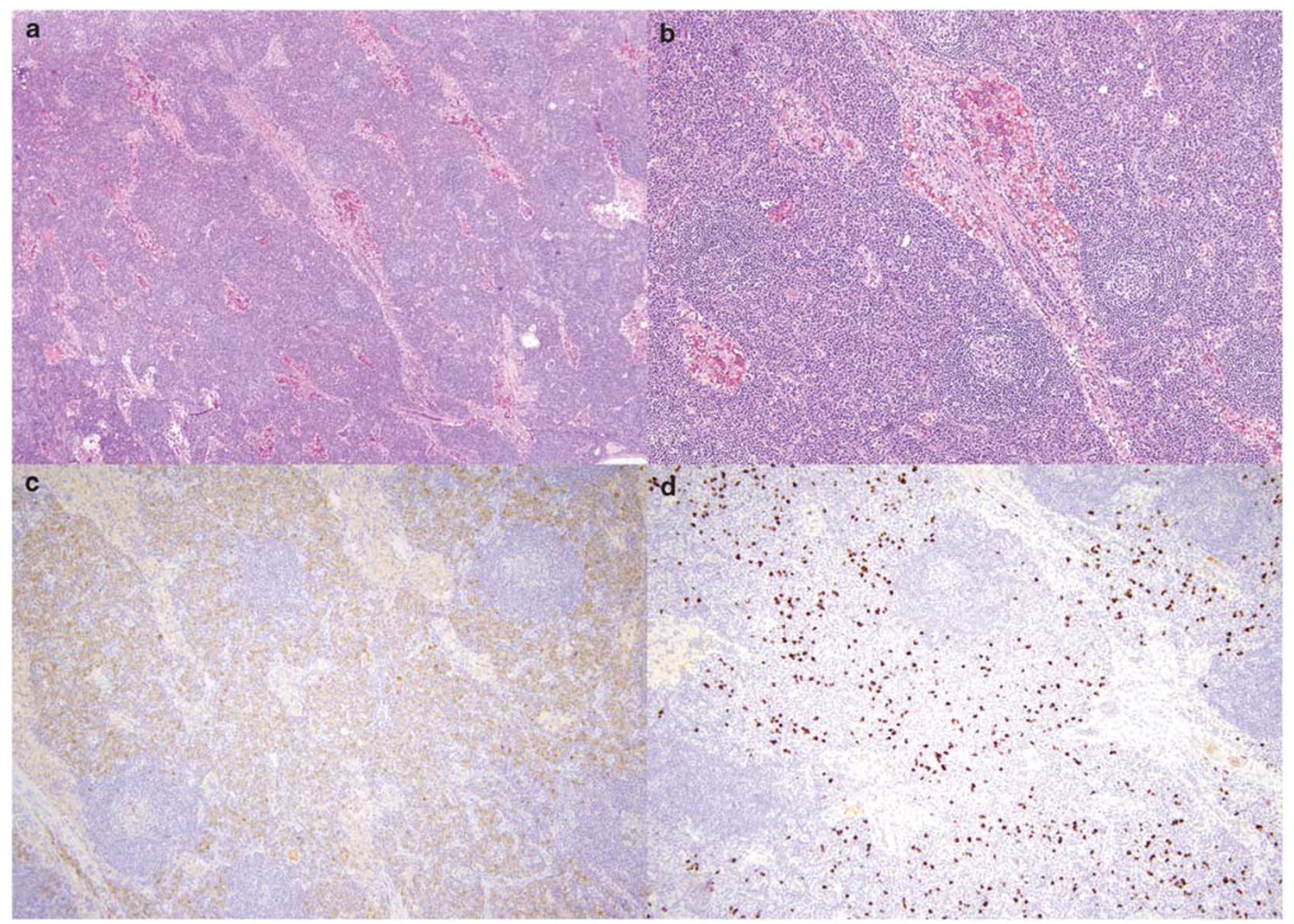

Figure 4 (a) low magnification, (b) intermediate magnification of plasma cell Castleman-like IgG4-related lymphadenopathy. Immunohistochemical staining for (c) IgG and (d) IgG4 with markedly increased IgG4-positive plasma cells.

serum elevation of IgG4. ${ }^{5}$ Serum elevations are thought to coincide with disease activity and the number of involved sites. Although helpful for diagnosis, an elevated serum IgG4 level is not required. Patients who have been diagnosed with IgG4-related sclerosing disease by fulfilling histological criteria may not have elevated serum levels (false negative), and elevated serum levels may be seen in other conditions, such as atopic dermatitis pemphigus and parasitic diseases (false positive). ${ }^{5}$ We would propose that on the basis of histopathological findings alone, our cases represent a manifestation of IgG4-related sclerosing disease, as the increase of IgG4-positive plasma cells is not seen in other types of lymphadenopathy analyzed in our series (Table 2).

In general, reactive lymph nodes are not a specific diagnostic challenge; however, their exact etiology is only rarely discernable using typical methodology. In our cases, we show that a number of lymph nodes with a broad range of reactive features are likely related to increase in IgG4-positive plasma cells, and may be part of the spectrum of IgG4related sclerosing disease. Compared with pediatric populations, reactive lymphadenopathy of sufficient size and clinical concern for biopsy in adults is relatively rare. Furthermore, in adult cases, the percentages of benign and reactive conditions are lower, whereas the incidences of both lymphoid and non-lymphoid neoplasms are increased. ${ }^{10}$ Notable morphological findings in our cases included follicular hyperplasia, inter- and intrafollicular plasmacytosis, progressively transformed germinal centers and interfollicular expansions. In these cases, the differential diagnostic considerations would include nonspecific follicular hyperplasia, nonspecific interfollicular or paracortical hyperplasias, nonspecific causes of progressively transformed germinal centers, autoimmune lymphadenitis, nodal plasmacytoma, plasma cell Castleman disease and rare cases of hyaline-vascular Castleman disease (Table 3). Exceedingly rarely, other infectious etiologies, such as nodal manifestations of syphilis (leutic lymphadenitis) could show some comparable findings. Likewise, the manifestations of autoimmune lymphadenitis may be comparable to those mentioned above. Although the findings in each of these diagnoses have some distinctive features, in many circumstances, they would not be sufficiently distinctive as to exclude a diagnosis 


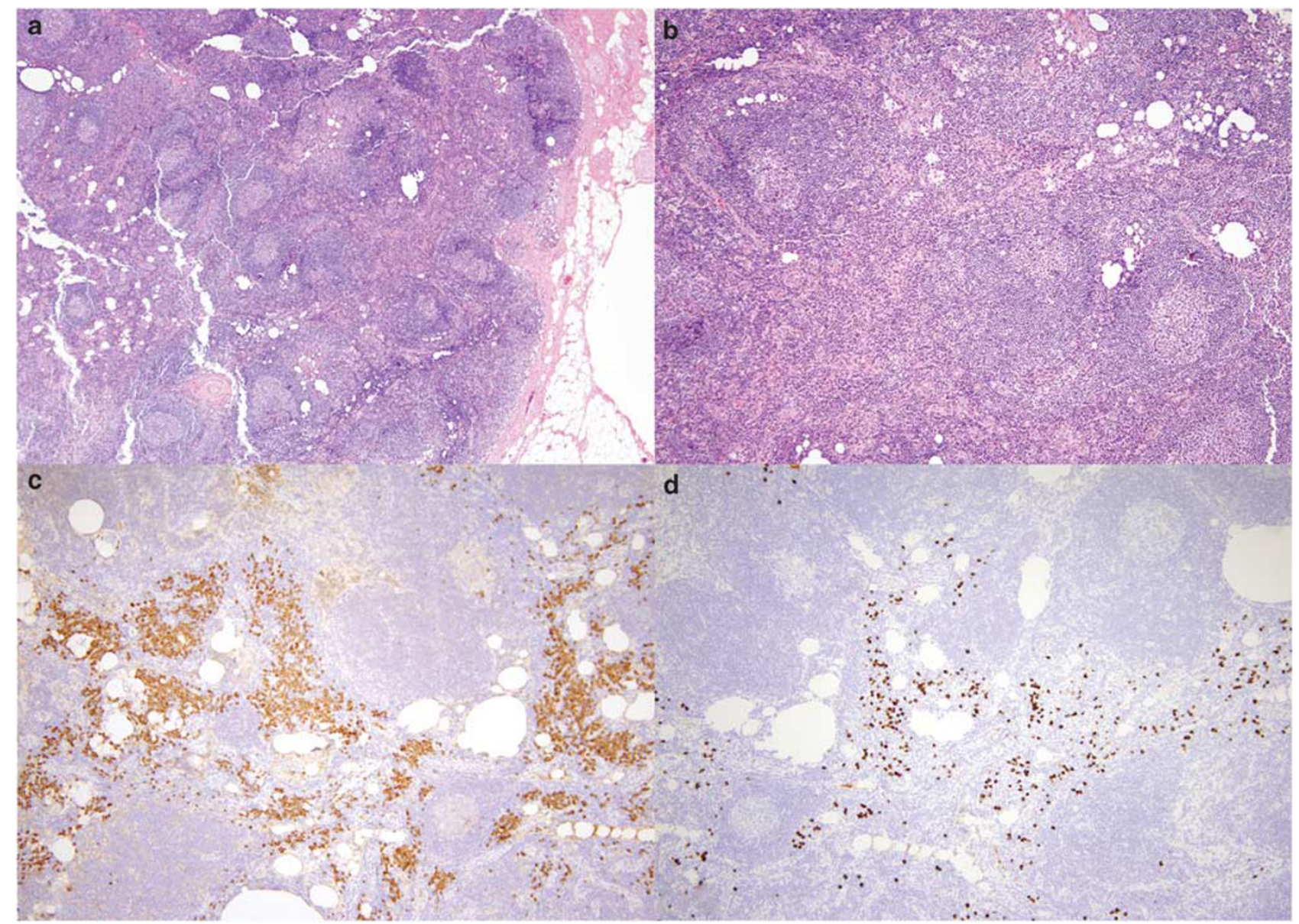

Figure 5 (a) low magnification, (b) intermediate magnification of an interfollicular expansion of plasma cells and transformed large lymphocytes. Immunohistochemical staining for (c) IgG and (d) IgG4 with increases in the latter beyond normal.

of IgG4-related lymphadenopathy. As such, testing for IgG4-positive lymph nodes in cases with a broad range of histological features may be warranted, especially in those of older patients.

Progressive transformation of germinal centers is a rare occurrence in lymph nodes of adults. Previous studies have shown that the mean age of progressively transformed germinal centers in adults is 28 years, representing a rare finding in older adults. ${ }^{11}$ In our experience, in cases of adults $>50$ years, progressively transformed germinal centers frequently have increased IgG4-positive plasma cells, and area strongly associated with IgG4-related lymphadenopathy. The presence of light chain restriction would support a neoplastic diagnosis or plasma cell Castleman disease and not be compatible with a diagnosis of IgG4-related lymphadenopathy. Likewise, diffuse sheets of large lymphocytes or other features of unequivocal malignancy would not warrant classification as IgG4-related lymphadenopathy. There are increasing numbers of reports of lymphoma associated with IgG4 production. ${ }^{12,13}$ Most of these have been marginal zone lymphomas with IgG4-positive clonal plasma cells. The relationship between IgG4-positive benign disorders and the subsequent development of IgG4-positive lymphomas has not been thoroughly evaluated at this point.

In addition, plasma cells within germinal centers are a rare finding in reactive lymph nodes. In the past, this finding has been suggested to be associated with autoimmune disease. ${ }^{14}$ However, our experience suggests that many of these cases have increased IgG4-positive plasma cells. This does not exclude the possibility of an association with autoimmune disease, but rather broadens the possible association of IgG4-related sclerosing disease with specific autoimmune disorders.

Our cases did not show the marked male predominance that has previously been described in other manifestations of IgG4-related sclerosing disease. In the past, it is possible that the cases involving women had seemed more compatible with autoimmune etiologies. Autoantibodies produced in IgG4-related sclerosing disease can include both antinuclear antibodies and rheumatoid factor, and, quite often, the sedimentation rate is elevated. ${ }^{5,15} \mathrm{We}$ would propose that IgG4 lymphadenopathy may coexist with autoimmune disorders or be a 'reaction pattern' in a subset of cases. Interestingly, it has been reported that 'occasional' patients with rheumatoid 


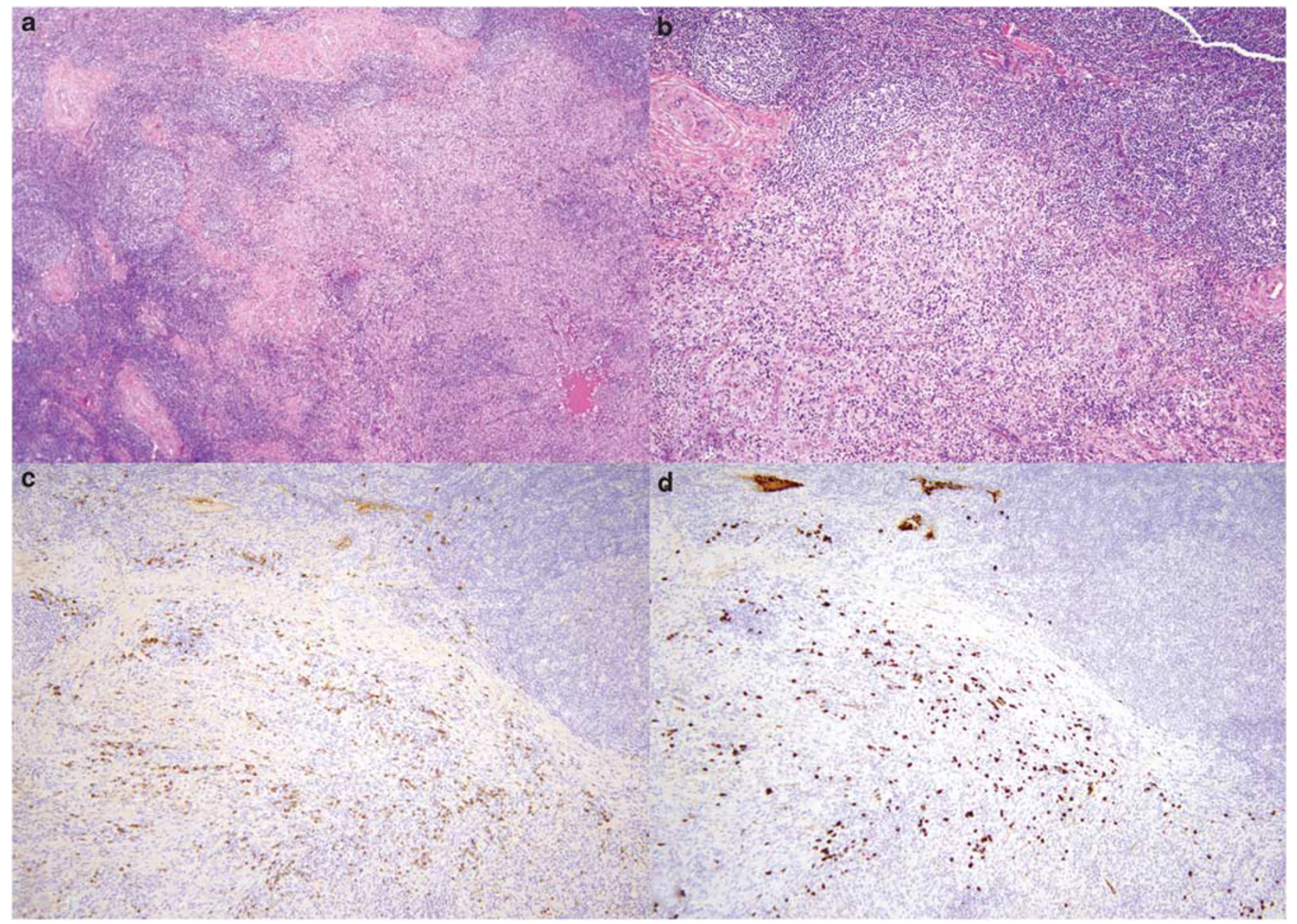

Figure 6 (a) low magnification, (b) intermediate magnification of a fibrotic, reactive lymph node. Immunohistochemical staining for (c) IgG and (d) IgG4.

arthritis have a high proportion of IgG4 plasma cells, but do not have morphological or clinical findings compatible with IgG4-related sclerosing disease. ${ }^{5}$ Whether these patients may progress to develop clinical and/or morphological findings of IgG4related sclerosing disease remains to be seen. One case in our reactive cohort had a known diagnosis of rheumatoid arthritis, with no increase in IgG4positive plasma cells. This suggests that cases of rheumatoid arthritis are not always associated with increases in IgG4-positive plasma cells.

Other reports have described IgG4-related sclerosing disease to occur in an older-to-elderly patient population. In contrast, our cases showed a younger population affected, with our youngest patient at age 19. This may be related to a bias in lymph node sampling and corresponding diagnostic evaluations. Benign/reactive lymph nodes are more common in younger patients but are less frequently excised.

Increased numbers of IgG4 plasma cells are seen in Rosai-Dorfman disease, cutaneous plasmacytosis, perforating collagenosis, autoimmune atrophic gastritis and sclerosing variant of mucoepidermoid carcinoma of salivary gland. ${ }^{5,16}$ One case in this series did show increased numbers of CD1a/s100positive Langerhans cells (Case 2), although the typical histological findings of Rosai-Dorfman disease were not evident. The relationship of these entities with increased numbers of IgG4 plasma cells to IgG4-related sclerosing disease has not been clearly demonstrated as yet.

The number of cases with a predominantly fibrotic background in this sampling was low $(32 \%)$. At extranodal sites, it has been suggested ${ }^{5}$ that this disease may start as an exuberant massforming lesion composed predominantly of a lymphoplasmacytic infiltrate with little fibrosis. Mass lesions that present at this 'early stage' tend to be superficial in location (such as the lacrimal gland) where even a small increase in size could trigger a biopsy. In contrast, 'later-stage' lesions tend to have less lymphoplasmacytic infiltrate, with an increased component of fibrosis. These lesions tend to present at sites that are less superficial, such as the pancreas, and tend to be sampled at a later stage, when the enlarging mass may impact surrounding structures and glandular function may be compromised. One explanation for fewer lymph node cases 
Table 1 Summary of findings in lymph nodes with increased IgG4 plasma cells

\begin{tabular}{|c|c|c|c|c|c|c|c|c|c|c|}
\hline Case & Gender & Age & Location & $F H$ & IFE & $P T G C$ & $F$ & $S / V$ & Intra-F PC & Inter-F PC \\
\hline 1 & $\mathrm{~F}$ & 52 & Axillary & + & + & + & & + & + & \\
\hline 2 & $\mathrm{~F}$ & 73 & Inguinal & + & + & + & + & + & + & \\
\hline 3 & $\mathrm{~F}$ & 74 & Inguinal & & & & + & + & & + \\
\hline 4 & $\mathrm{~F}$ & 77 & Axillary & + & & + & & + & + & \\
\hline 5 & $\mathrm{~F}$ & 55 & Cervical & & + & & & & & + \\
\hline 6 & $\mathrm{~F}$ & 50 & Axillary & + & + & + & & & + & + \\
\hline 7 & M & 44 & Mediastinal & & + & & & + & & + \\
\hline 8 & M & 61 & Axillary & + & + & + & & + & + & + \\
\hline 9 & M & 19 & Inguinal & + & + & & + & + & & + \\
\hline 10 & $\mathrm{~F}$ & 69 & Cervical & & & & & & + & \\
\hline 11 & M & 55 & Axillary & + & + & & & + & & \\
\hline 12 & M & 72 & Cervical & + & + & + & & & + & + \\
\hline 13 & $\mathrm{~F}$ & 66 & Axillary & & & & & + & & + \\
\hline 14 & $\mathrm{~F}$ & 49 & Inguinal & + & + & & & & & + \\
\hline 15 & $\mathrm{~F}$ & 44 & Cervical & + & + & + & & + & & + \\
\hline 16 & $\mathrm{~F}$ & 41 & Axillary & + & + & + & & & + & \\
\hline 17 & M & 31 & Submental & + & + & & + & + & & \\
\hline 18 & $\mathrm{~F}$ & 60 & Axillary & + & + & & + & & + & + \\
\hline 19 & M & 47 & Cervical & + & + & + & & & + & + \\
\hline 20 & $\mathrm{~F}$ & 52 & Not given & + & + & + & & & & \\
\hline 21 & $\mathrm{~F}$ & 51 & Cervical & + & + & & & & + & + \\
\hline 22 & $\mathrm{~F}$ & 63 & Cervical & + & + & & + & + & + & + \\
\hline 23 & $\mathrm{~F}$ & 58 & Not given & + & + & + & & + & + & + \\
\hline 24 & M & 31 & Axillary & + & + & & + & & & + \\
\hline 25 & M & 77 & Inguinal & + & + & & & + & + & + \\
\hline 26 & $\mathrm{~F}$ & 71 & Chest wall & + & + & & + & + & & + \\
\hline 27 & $\mathrm{~F}$ & 47 & Cervical & + & + & + & & + & + & + \\
\hline 28 & M & 83 & Axillary & + & + & + & + & + & + & + \\
\hline 29 & $\mathrm{~F}$ & 78 & Cervical & + & + & + & & + & & \\
\hline
\end{tabular}

FH, follicular hyperplasia; IFE, interfollicular expansion; PTGC, progressive transformation of germinal centers; F, fibrosis; S/V, stromal/vascular proliferation; Intra-F PC, intra-follicular plasma cells; Inter-F PC, inter-follicular plasma cells; P, prominent findings.

Table 2 Reactive lymph nodes with minimal IgG4 staining

\begin{tabular}{|c|c|c|c|c|c|c|c|c|c|c|c|c|c|}
\hline Case & Site & Age & Gender & $F H$ & IFE & PTGC & Fibrosis & $S / V$ & Intra-F PC & Inter-F PC & $\begin{array}{l}\text { Histiocyte } \\
\text { proliferation }\end{array}$ & $\begin{array}{l}\text { IgG4/ } \\
H P F\end{array}$ & Comment \\
\hline 1 & Neck & 65 & $\mathrm{~F}$ & $\mathrm{~N}$ & $\mathrm{Y}$ & $\mathrm{N}$ & $\mathrm{N}$ & $\mathrm{N}$ & $\mathrm{N}$ & $\mathrm{Y}$ & $\begin{array}{l}\text { + Numerous, } \\
\text { diffuse }\end{array}$ & $<1 / 10$ & $\begin{array}{l}\text { EBV+ plasma } \\
\text { cells, PTLD-like }\end{array}$ \\
\hline 2 & Appendix & 17 & M & $\mathrm{Y}$ & $\mathrm{Y}$ & $\mathrm{N}$ & $\mathrm{N}$ & $\mathrm{Y}$ & $\mathrm{N}$ & $\mathrm{Y}$ & $\mathrm{Y}$ & $<1 / 10$ & $\begin{array}{l}\text { Immunoblastic } \\
\text { hyperplasia + } \\
\text { PC }\end{array}$ \\
\hline 3 & Facial LN & 54 & M & $\mathrm{N}$ & $\mathrm{Y}$ & $\mathrm{N}$ & $\mathrm{Y}$ & $\mathrm{Y}$ & $\mathrm{N}$ & $\mathrm{Y}$ & $\mathrm{Y}$ & $<1 / 10$ & $\begin{array}{l}\text { Polyclonal } \\
\text { plasmacytosis } \\
\text { post-therapy for } \\
\text { CLL }\end{array}$ \\
\hline 4 & Inguinal LN & 63 & M & $\mathrm{N}$ & $\mathrm{N}$ & $\mathrm{N}$ & $\mathrm{Y}$ & $\mathrm{Y}$ & $\mathrm{N}$ & $\mathrm{N}$ & $\mathrm{Y}$ & $<1 / 10$ & IPT-like \\
\hline 5 & Neck & 21 & $\mathrm{M}$ & $\mathrm{Y}$ & $\mathrm{N}$ & $\mathrm{Y}$ & $\mathrm{N}$ & $\mathrm{N}$ & $\mathrm{N}$ & $\mathrm{N}$ & $\mathrm{N}$ & $<1 / 10$ & Florid PTGC \\
\hline 6 & Neck & 39 & M & $\mathrm{Y}$ & $\mathrm{Y}$ & $\mathrm{N}$ & $\mathrm{N}$ & $\mathrm{N}$ & $\mathrm{Y}$ & $\mathrm{Y}$ & $\mathrm{N}$ & $<1 / 10$ & $\begin{array}{l}\text { PC CD, HHV8 } \\
\text { negative }\end{array}$ \\
\hline 7 & Axilla & 38 & $\mathrm{~F}$ & $\mathrm{Y}$ & $\mathrm{Y}$ & $\mathrm{N}$ & $\mathrm{N}$ & $\mathrm{Y}$ & $\mathrm{Y}$ & $\mathrm{Y}$ & $\mathrm{N}$ & $<1 / 10$ & $\begin{array}{l}\text { Immunoblastic } \\
\text { hyperplasia }\end{array}$ \\
\hline 8 & Inguinal & 49 & & $\mathrm{~N}$ & $\mathrm{~N}$ & $\mathrm{~N}$ & $\mathrm{Y}$ & $\mathrm{Y}$ & $\mathrm{N}$ & $\mathrm{Y}$ & $\mathrm{N}$ & $<1 / 10$ & $\begin{array}{l}\text { Reactive. } \\
\text { history of RA }\end{array}$ \\
\hline 9 & Parotid LN & 42 & $\mathrm{~F}$ & $\mathrm{Y}$ & $\mathrm{Y}$ & $\mathrm{Y}$ & $\mathrm{N}$ & $\mathrm{N}$ & $\mathrm{N}$ & $\mathrm{N}$ & $\mathrm{N}$ & $<1 / 10$ & \\
\hline 10 & Axilla & 11 & $\mathrm{~F}$ & $\mathrm{Y}$ & $\mathrm{N}$ & $\mathrm{Y}$ & $\mathrm{N}$ & $\mathrm{N}$ & $\mathrm{Y}$ & $\mathrm{N}$ & $\mathrm{N}$ & $<1 / 10$ & \\
\hline 11 & Groin & 32 & $\mathrm{~F}$ & $\mathrm{Y}$ & $\mathrm{N}$ & $\mathrm{N}$ & $\mathrm{N}$ & $\mathrm{Y}$ & $\mathrm{N}$ & $\mathrm{N}$ & $\mathrm{N}$ & $<1 / 10$ & $\begin{array}{l}\text { EBV-associated } \\
\text { hyperplasia }\end{array}$ \\
\hline 12 & Axilla & 48 & M & $\mathrm{Y}$ & $\mathrm{N}$ & $\mathrm{N}$ & $\mathrm{N}$ & $\mathrm{N}$ & $\mathrm{N}$ & $\mathrm{N}$ & $\mathrm{N}$ & $<1 / 10$ & \\
\hline 13 & Peritoneal & 38 & $\mathrm{~F}$ & $\mathrm{Y}$ & $\mathrm{Y}$ & $\mathrm{N}$ & $\mathrm{Y}$ & $\mathrm{Y}$ & $\mathrm{N}$ & $\mathrm{N}$ & $\mathrm{N}$ & $<1 / 10$ & $\begin{array}{l}\text { Hyaline- } \\
\text { vascular } \\
\text { Castleman }\end{array}$ \\
\hline 14 & Axilla & 18 & $\mathrm{~F}$ & $\mathrm{Y}$ & $\mathrm{Y}$ & $\mathrm{N}$ & $\mathrm{Y}$ & $\mathrm{Y}$ & $\mathrm{N}$ & $\mathrm{N}$ & $\mathrm{N}$ & $<1 / 10$ & $\begin{array}{l}\text { Hyaline- } \\
\text { vascular } \\
\text { Castleman }\end{array}$ \\
\hline 15 & Axilla & 70 & $\mathrm{~F}$ & $\mathrm{Y}$ & $\mathrm{Y}$ & $\mathrm{N}$ & $\mathrm{N}$ & $\mathrm{Y}$ & $\mathrm{N}$ & $\mathrm{Y}$ & $\mathrm{N}$ & $<1 / 10$ & $\begin{array}{l}\text { Polyclonal } \\
\text { nodal } \\
\text { plasmacytosis }\end{array}$ \\
\hline 16 & Neck & 74 & $\mathrm{M}$ & $\mathrm{Y}$ & $\mathrm{N}$ & $\mathrm{N}$ & $\mathrm{N}$ & $\mathrm{Y}$ & $\mathrm{Y}$ & $\mathrm{Y}$ & $\mathrm{N}$ & $<1 / 10$ & \\
\hline 17 & Axillary & 43 & $\mathrm{~F}$ & Y & $\mathrm{Y}$ & $\mathrm{Y}$ & $\mathrm{N}$ & $\mathrm{N}$ & $\mathrm{Y}$ & $\mathrm{Y}$ & $\mathrm{N}$ & $<1 / 10$ & \\
\hline 18 & Neck & 46 & $\mathrm{~F}$ & $\mathrm{Y}$ & $\mathrm{Y}$ & $\mathrm{Y}$ & $\mathrm{N}$ & $\mathrm{N}$ & $\mathrm{N}$ & $\mathrm{N}$ & $\mathrm{N}$ & $<1 / 10$ & \\
\hline 19 & Inguinal & 50 & $\mathrm{~F}$ & $\mathrm{Y}$ & $\mathrm{Y}$ & $\mathrm{N}$ & $\mathrm{N}$ & $\mathrm{Y}$ & $\mathrm{Y}$ & $\mathrm{Y}$ & $\mathrm{N}$ & $<1 / 10$ & PC-CD-like \\
\hline
\end{tabular}

FH, follicular hyperplasia; IFE, interfollicular expansion; IPT, inflammatory pseudotumor; PTGC, progressive transformation of germinal centers; S/V, stromal/vascular proliferation; Intra-F PC, intra-follicular plasma cells; Inter-F PC, inter-follicular plasma cells; CLL, chronic lymphocytic leukemia; PC-CD, plasma cell Castleman disease; PTLD, post-transplant lymphoproliferative disorder; RA, rheumatoid arthritis. 

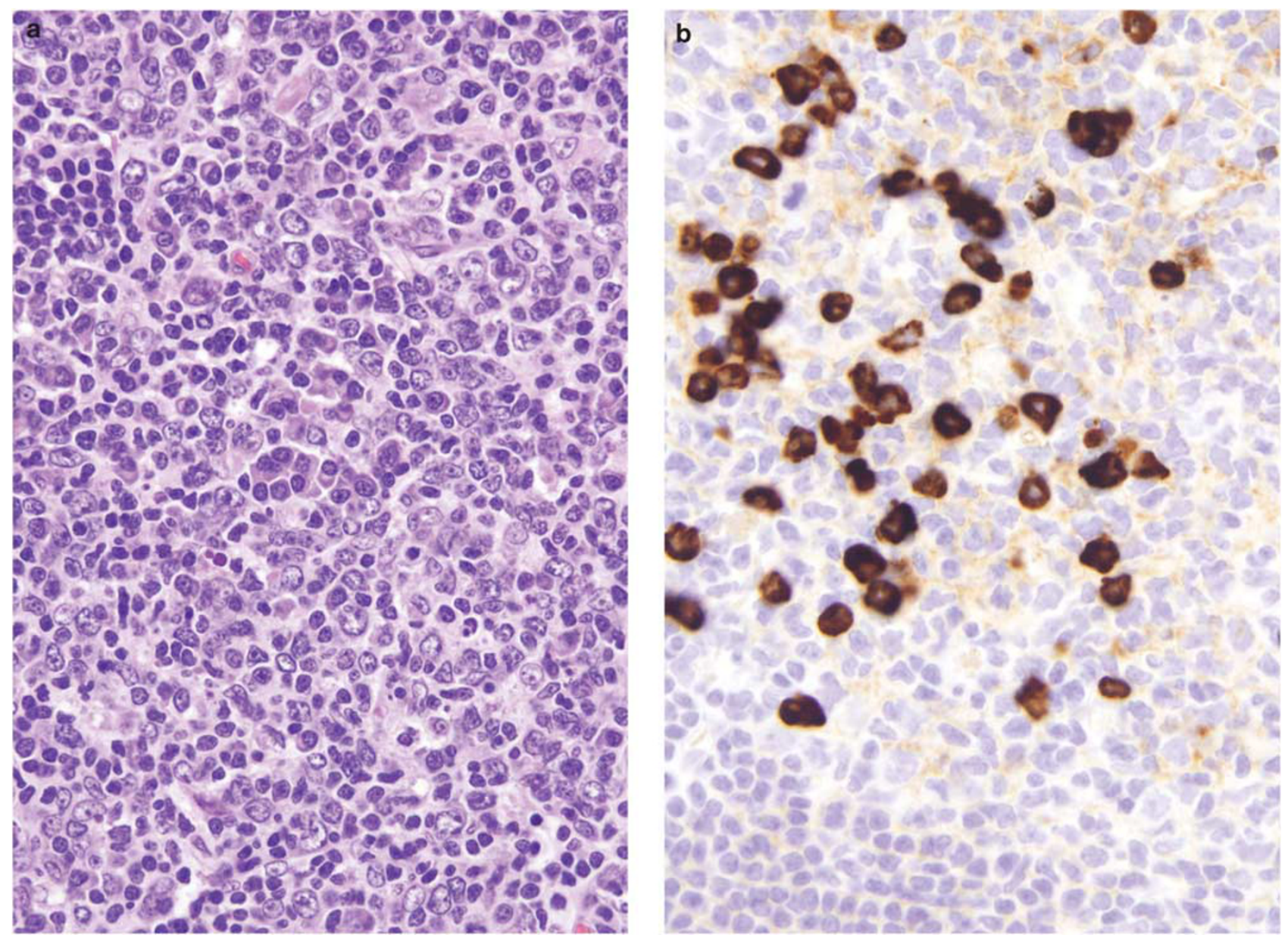

Figure 7 (a) High magnification image of intrafollicular plasma cells, with (b) many cells positive for IgG4.

with a fibrotic component may be that these lymph nodes are biopsied relatively soon after they become enlarged (ie, at the early stage) owing to clinical suspicion of lymphoma.

Cases included in this series represent lymph node resections. Patchy, uneven distribution of IgG4 plasma cells was seen in our cases. Given this finding, negative staining evaluations of IgG4 on needle core biopsies might not be sufficient to exclude IgG4-related lymphadenopathy. In cases such as plasma cell Castleman disease or other causes of nodal plasmacytosis, the histopathological findings in a limited sample (eg needle core biopsy) may be indistinguishable from IgG4-related lymphadenopathy.

Flow cytometry demonstrated an increase in $\mathrm{CD} 4+\mathrm{T}$ cells compared with CD8 $+\mathrm{T}$ cells, as would be expected in 'reactive' lymph nodes. No aberrant $\mathrm{T}$ cell antigenic expression or loss was observed. We noted a small population of dual CD4 + CD8 + T-cells in most of our cases. Populations of CD4 and CD8 coexpressing T cells may be seen in nodular lymphocyte-predominant Hodgkin's lymphoma, an entity in which progressively trans- formed germinal center-like changes are a prominent histological finding. ${ }^{17}$ In the cases where a discrete population was noted, the size of the population was very small in comparison with the prominent populations described in nodular lymphocyte-predominant Hodgkin's lymphoma.

The underlying pathobiology of IgG4-related sclerosing disease is not known. It is unclear whether the IgG4-positive plasma cells are causative of the pathological process seen, or are only a marker for an as-yet undescribed etiology or etiologies. ${ }^{6}$ In spite of this, the recognition of IgG4-related diseases and related lymphadenopathy is of increasing importance. Because IgG4-related sclerosing disease is systemic and progressive, timely diagnosis is critical. Without appropriate treatment, the disease will progress, resulting in loss of function of potentially any exocrine gland as well as local destruction from mass-forming lesions and fibrosis at many sites/organs throughout the body. IgG4related sclerosing disease has been shown to be exquisitely responsive to steroids and also amenable to rituximab; $;^{3,5,18}$ prompt diagnosis and treatment will prevent significant patient morbidity and 
Table 3 Comparison of IgG4-related lymphadenopathy to possible differential diagnoses

\begin{tabular}{|c|c|c|c|c|c|c|c|}
\hline & $\begin{array}{c}\text { Follicular } \\
\text { hyperplasia }\end{array}$ & $\begin{array}{l}\text { Interfollicular } \\
\text { expansion }\end{array}$ & $\begin{array}{l}\text { Intrafollicular } \\
\text { plasma cells }\end{array}$ & $\begin{array}{l}\text { Interfollicular } \\
\text { plasma cells }\end{array}$ & PTGC & $\begin{array}{l}\text { Fibrosis } \\
\text { or sclerosis }\end{array}$ & Comment \\
\hline $\begin{array}{l}\text { IgG4-related } \\
\text { lymphadenopathy }\end{array}$ & + & + & $+1-$ & + & $+1-$ & $+1-$ & Usually older patients \\
\hline $\begin{array}{l}\text { Typical follicular } \\
\text { hyperplasia }\end{array}$ & + & $-/+$ & $-/+$ & - & - & - & $\begin{array}{l}\text { Wide variety of } \\
\text { etiologies }\end{array}$ \\
\hline Typical PTGC & + & - & $-1+$ & - & + & - & $\begin{array}{l}\text { Usually younger } \\
\text { patients }\end{array}$ \\
\hline $\begin{array}{l}\text { Typical interfollicular/ } \\
\text { paracortical } \\
\text { hyperplasia }\end{array}$ & $-1+$ & + & - & - & - & $-/+$ & $\begin{array}{l}\text { Variety of etiologies } \\
\text { although } \\
\text { some cases are viral } \\
\text { infection associated }\end{array}$ \\
\hline $\begin{array}{l}\text { Plasma cell Castleman } \\
\text { disease }\end{array}$ & $-/+$ & + & - & + & - & $-1+$ & $\begin{array}{l}\text { Plasma cells are } \\
\text { monoclonal } \\
\text { lambda in about } 1 / 2 \\
\text { of cases }\end{array}$ \\
\hline $\begin{array}{l}\text { Hyaline-vascular } \\
\text { Castleman disease }\end{array}$ & $t^{\mathrm{a}}$ & + & - & - & - & + & $\begin{array}{l}\text { Dysplastic dendritic } \\
\text { cells are seen }\end{array}$ \\
\hline Nodal plasmacytoma & - & + & - & + & - & $-/+$ & $\begin{array}{l}\text { Nodal replacement by } \\
\text { monoclonal plasma } \\
\text { cells; often IgA- } \\
\text { positive }\end{array}$ \\
\hline
\end{tabular}

PTGC, progressively transformed germinal centers.

${ }^{\mathrm{a}}$ There is an overall increase in follicles (eg hyperplasia), which are reduced in size/atretic, in comparison with typical hypertrophied follicular seen in usual follicular hyperplasia.

eliminate the risks of unnecessary surgical interventions. Increasing the recognition and diagnosis of IgG4-related lymphadenopathy will not only provide a better clinical outcome for patients, but will also provide a better understanding of underlying disease etiology.

\section{Acknowledgement}

We acknowledge the excellent technical assistance of Yop Jun and Kathleen Aglubat.

\section{Disclosure/conflict of interest}

The authors declare no conflict of interest.

\section{References}

1 Yoshida K, Toki F, Takeuchi T, et al. Chronic pancreatitis caused by an autoimmune abnormality. Proposal of the concept of autoimmune pancreatitis. Dig Dis Sci 1995;40:1561-1568.

2 Chari ST, Smyrk TC, Levy MJ, et al. Diagnosis of autoimmune pancreatitis: the Mayo Clinic experience. Clin Gastroenterol Hepato 2006;4:1010-1016.

3 Masaki Y, Kurose N, Umehara H. IgG4-Realted disease: a novel lymphoproliferative disorder discorvered and established in Japan in the 21st century. J Clin Exp Hematopatho 2011;51:13-19.

4 Sato Y, Notohara K, Kojima M, et al. IgG4-related disease: historical overview and pathology of hematological disorders. Pathol Int 2010;60:247-258.
5 Cheuk W, Chan JKC. IgG4-related sclerosing disease: a critical appraisal of an evolving clinicopathologic entity. Adv Anat Patho 2010;17:303-332.

6 Nirula A, Glaser SM, Kalled SL, et al. What is IgG4? A review of the biology of a unique immunoglobulin subtype. Curr Opin Rheumato 2011;23:119-124.

7 Cheuk W, Yuen HK, Chu SYY, et al. Lymphadenopathy of IgG4-related sclerosing disease. Am J Surg Patho 2008;32:671-681.

8 Sato Y, Kojima M, Takata K, et al. Systemic IgG4related lymphadenopathy: a clinical and pathologic comparison to multicentric Castleman's disease. Mod Patho 2009;22:589-599.

9 Saab ST, Hornick JL, Fletcher CD, et al. IgG4 plasma cells in inflammatory myofibroblastic tumor: inflammatory marker or pathogenic link? Mod Patho 2011;24:606-612.

10 Morris-Stiff G, Cheang P, Key S, et al. Does the surgeon still have a role to play in the diagnosis and management of lymphomas? World J Surg Oncol 2008;6:13.

11 Hicks J, Flaitz C. Progressive transformation of germinal centers: review of histopathologic and clinical features. Int J Pediatr Otorhinolaryngo 2002;65:195-202.

12 Cheuk W, Yuen HK, Chan AC, et al. Ocular adnexal lymphoma associated with IgG4+ chronic sclerosing dacryoadenitis: a previously undescribed complication of IgG4-related sclerosing disease. Am J Surg Patho 2008;32:1159-1167.

13 Sato Y, Takata K, Ichimura K, et al. IgG4-producing marginal zone B-cell lymphoma. Int J Hemato 2008;88:428-433.

14 O’Malley DP, George TI, Orazi A, et al. Systemic and autoimmune abnormalities. In: Atlas of Nontumor Pathology: Benign and Reactive Conditions of Lymph Node and Spleen. ARP Press: Washington, 2009, pp 375-404. 
15 Lim EJ, Bhathal PS, Tagkalidis PP, et al. Catching a chameleon: IgG4-related systemic disease. MJA 2010;193:418-420.

16 Strehl JD, Hartman A, Agaimy A. Numerous IgG4positive plasma cells are ubiquitous in diverse localized non-specific chronic inflammatory conditions and need to be distinguished from IgG4-related systemic disorders. J Clin Patho 2011;64:237-243.
17 Rahemtullah A, Reichard KK, Preffer FI, et al. A doublepositive CD4+CD8+ T-cell population is commonly found in nodular lymphocyte predominant Hodgkin lymphoma. Am J Clin Patho 2006;126:805-814.

18 Khosroshahi A, Bloch DB, Deshpande V, et al. Rituximab therapy leads to a rapid decline of serum IgG4 levels and prompt clinical improvement in IgG4-related systemic disease. Arthritis Rheum 2010;62:1755-1762. 